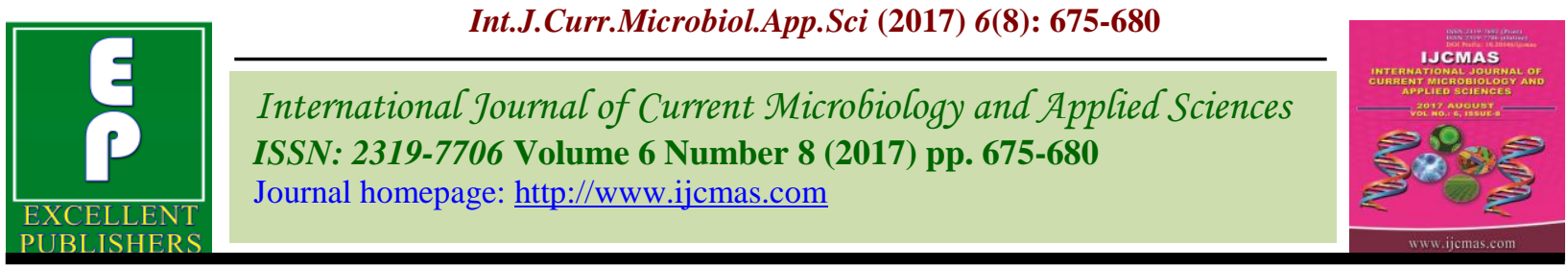

Original Research Article https://doi.org/10.20546/ijcmas.2017.608.085

\title{
Dissipation Pattern of Bifenthrin on Dolichos Bean
}

\author{
S. Srinivasa Reddy ${ }^{*}$, C. Narendra Reddy, C. Srinivas, \\ A. Manohar Rao and S. Narendar Reddy \\ College of Agriculture, PJTSAU, Rajendranagar, Hyderabad-500 030, T.S., India \\ *Corresponding author
}

\begin{abstract}
A B S T R A C T
Keywords

Insecticides,

Pests, Initial deposit, Efficacy and dissipation.

Article Info

Accepted:

04 June 2017

Available Online:

10 August 2017

An experiment was conducted during kharif, 2015 to evaluate the efficacy of eight insecticides viz., fipronil 5\% SC, flubendamide $480 \%$ SC, chlorantraniliprole $20 \%$ $\mathrm{SC}$, bifenthrin $10 \% \mathrm{EC}$, profenophos $50 \% \mathrm{EC}$, lambda cyhalothrin $5 \% \mathrm{SC}$, imidacloprid $17.8 \%$ SL and beta cyfluthrin + imidacloprid 300 OD were studied by spraying thrice replicated thrice in randomized block design on field bean @

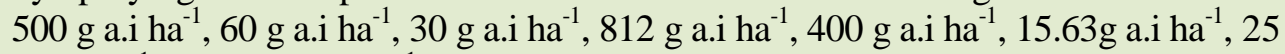
$\mathrm{g}$ a.i ha ${ }^{-1}$ and $30 \mathrm{~g}$ a.i ha ${ }^{-1}$, respectively. Against major insect pests of field bean, the dissipation pattern of bifenthrin $10 \% \mathrm{EC}\left(25 \mathrm{~g}\right.$ a.i.ha $\left.{ }^{-1}\right)$ was studied by collecting samples at regular intervals i.e. $0,1,3,5,7,10$ and 15days after last spray and analyzed. The initial deposits of $2.62 \mathrm{mg} \mathrm{kg}^{-1}$ profenophos recorded at 2 hours after last spray dissipated to $1.74,0.74$ and $0.22 \mathrm{mg} \mathrm{kg}^{-1}$ at 1,3 and 5 days, after last spray respectively and below determination level (BDL) by $7^{\text {th }}$ day.
\end{abstract}

\section{Introduction}

Pulse crops belong to the family Leguminosae and subfamilies Papilionoideae, Caesalpinoideae and Mimosoideae. They were narrated as the jewels of Indian agriculture, in view of their unique capacity to fill the dietary requirements of protein to thirsty population of rural India, besides their sustainable character through replenishing soil fertility.

The average protein content varies from 18 to 26 per cent. Lablab purpureus (L.) Sweet. Popularly known as field bean, hyacinth bean, dolichos bean, country bean, butter bean, and Indian bean which is an important pulse cum vegetable crop in India and is cultivated extensively in recent past for its fresh tender pods, leaves and seeds and as cattle feed. The fresh and dried seeds constitute major vegetarian source of proteins in the human diet of Indians.

The field bean fresh pods are acceptable and liked by all, especially during winter season under South Indian conditions and it is rich in nutritive value as it is a rich source of carbohydrates, minerals, vitamins, such as vitamin $\mathrm{A}$, vitamin $\mathrm{C}$, fat and fiber. The protein content of field bean is quite high varying from 20.0 to 28.0 per cent (Schaaffhausen, 1963). However, some of these insecticides leave residues on pods and these residues may persist up to harvest. Presence of pesticide residues in the harvested 
beans was posing problem at the time of export and in recent times importing countries have rejected few consignments. Pesticide use has increased rapidly over the last two decades at the rate of 12 per cent per year. The extensive and irrational use of pesticides resulted in the presence of residues of insecticides on beans is likely to be associated with severe effects on human health. Hence, great significance has to be given to estimate pesticide residues in beans.

\section{Materials and Methods}

The experiment was laid out in a Randomized Block Design (RBD) with 9 treatments including untreated control replicated thrice with individual plot size of $20 \mathrm{~m}^{2}(5 \mathrm{mx} 4 \mathrm{~m})$ and the insecticides viz., fipronil $5 \% \mathrm{SC}$, flubendamide $480 \%$ SC, chlorantraniliprole $20 \%$ SC, bifenthrin $10 \%$ EC, profenophos $50 \%$ EC, lambda cyhalothrin 5\% SC, imidacloprid $17.8 \%$ SL and beta cyfluthrin + imidacloprid 300 OD were studied by spraying thrice replicated thrice in randomized block design on field bean @ 500 $\mathrm{g}$ a.i ha ${ }^{-1}, 60 \mathrm{~g} \mathrm{a.i} \mathrm{ha}^{-1}, 30 \mathrm{~g}$ a.i ha ${ }^{-1}, 812 \mathrm{~g}$ a.i

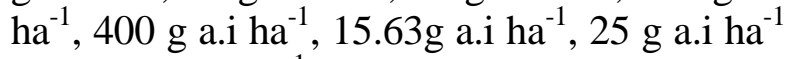
and $30 \mathrm{~g}$ a.i ha ${ }^{-1}$, respectively on field bean first at $50 \%$ flowering and the second and third spray ten days later to evaluate the efficacy against major insect pests and the dissipation studies were conducted for the same by collecting samples at regular intervals i.e. 0, $1,3,5,7,10$ and 15 days after last spray in polythene bags and brought to the laboratory immediately for further sample processing in the laboratory as detailed here under.

\section{Fortification and recovery results of bifenthrin on beans}

Field bean samples fortified with bifenthrin at $0.05 \mathrm{mg} \mathrm{kg}^{-1}, 0.25 \mathrm{mg} \mathrm{kg}^{-1}$ and $0.50 \mathrm{mg} \mathrm{kg}^{-1}$ were analyzed under GC-ECD and the mean recovery of the residues using the method was
$84.78,84.36$ and 92.52 per cent, respectively (Table 2). The results shown that the method was suitable for the analysis of bifenthrin residues up to $0.05 \mathrm{mg} \mathrm{kg}^{-1}$, and the limit of quantification (LOQ) was $0.05 \mathrm{mg} \mathrm{kg}^{-1}$.

Hence, the method described above is suitable for the analysis of samples collected from the field sprayed with bifenthrin residues to study the residue dynamics/dissipation pattern. Samples of beans were collected from profenophos@400 g a.i./ha sprayed plots at regular intervals i.e. $0,1,3,5,7,10$ and 15 days after last spray, and analysed for residues following the validated methods. Residues ( $\mathrm{mg} \mathrm{kg}^{-1}$ ) were calculated using the formula given below.

Sample peak area $X$ conc of std (ppm) X $\mu l$ std. injected $X$ Final volume of the Sample $(2 \mathrm{ml})$

Residues

$\left(\mathrm{mg} \mathrm{kg}^{-1}\right)=$--------------- $\mathrm{X}$ recovery factor

Standard Peak area $X$ weight of sample

Analysed (2 g) X $\mu$ l of sample injected

The following parameters were calculated to know the dissipation pattern of the insecticides on cabbage.

\section{Dissipation percentage}

Initial deposit - Residues at given time

Per cent dissipation $=$---------------- X 100
Initial deposit

\section{Waiting period}

Waiting period $\left(\mathrm{T}_{\mathrm{tol}}\right)$ is defined as the minimum number of days to lapse before the insecticide reaches the tolerance limit. The waiting periods were calculated by the following formula.

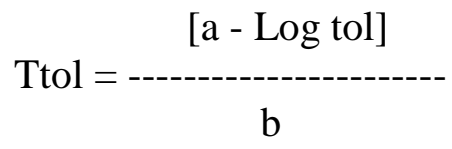

Where, 
$\mathrm{T}_{\mathrm{tol}}=$ Minimum time (in days) required for the pesticideresi due to reach below the tolerance limit.

$\mathrm{a}=\log$ of apparent initial deposits obtained in the regression equation $(\mathrm{Y}=\mathrm{a}+\mathrm{bX})$

tol $=$ Tolerance limit of the insecticide (MRL)

$\mathrm{b}=$ Slope of the regression line

\section{Results and Discussion}

The field bean crop after attaining of 50 per cent flowering with 10 days sequential interval of three sprayings were sprayed with bifenthrin 10\% EC @ $812 \mathrm{~g} \mathrm{a.i} \mathrm{ha}^{-1}$ and the pod samples were collected at regular intervals of zero (2 hours after spray), 1, 3, 5, 7, 10 and 15 days after third spray on field bean. The samples were processed and estimated for residues of fipronil on Gas Chromotography (GC-ECD) (Table 1). The dissipation pattern were presented in table 3 and depicted in figure 1. Initial deposit of bifenthrin was recorded as $2.62 \mathrm{mg} \mathrm{kg}^{-1}$. The residues recorded at 1,3 and $5^{\text {th }}$ day after third spraying were found to be $1.74,0.74$ and $0.22 \mathrm{mg} \mathrm{kg}^{-1}$, respectively and showing a dissipation per cent of 33.59, 71.76 and 91.60, respectively.

The residues were below detectable level (BDL) after 7 days showing 100 per cent dissipation. The regression equation was $\mathrm{Y}=$ $2.3841+(-0.4685) X$ with $R^{2}$ value of 0.9486 .

There were no MRLs suggested for bifenthrinin field bean by either Codex Alimentarius Commission (CAC) or by Food Safety and Standards Authority of India

(FSSAI), hence the day at which the bifenthrin residues reached below detectable level ( $7^{\text {th }}$ day) was considered as safe waiting period.

Since sufficient literature was not available on the dissipation pattern of bifenthrin on field beans, the information available on other crops was also taken into account for discussion.

Table.1 Gas chromatograph parameters

\begin{tabular}{|c|c|}
\hline Gas Chromatograph & Gas Chromatography- AGILENT- 7890B \\
\hline Column & $\begin{array}{l}\text { VF-5ms Capillary Column } \\
30 \mathrm{~m} \text { length, } 0.25 \mathrm{~mm} \text { Internal Diameter, } 0.25 \square \mathrm{m} \\
\text { film thickness; } 1 \% \text { methyl siloxane }\end{array}$ \\
\hline Column Oven $\left({ }^{\circ} \mathrm{C}\right)$ & $\begin{array}{l}\text { Bifenthrin - Initial } 200^{\circ} \mathrm{C} \text { for } 6 \mathrm{~min} \text { - increase @ } \\
20^{\circ} \mathrm{C} / \mathrm{min} \text { upto } 280^{\circ} \mathrm{C} \text { - hold for } 10 \mathrm{~min} . \\
\end{array}$ \\
\hline Detectors & Electron Capture Detector (ECD) \\
\hline Detector Temperature $\left({ }^{0} \mathrm{C}\right)$ & 300 \\
\hline Injector Temperature $\left({ }^{0} \mathrm{C}\right)$ & 280 \\
\hline Injector Status & Split Ratio: $1: 2$ \\
\hline Carrier Gas & Nitrogen, Iolar II, Purity 99.999\% \\
\hline Carrier Gas Flow $\left(\mathrm{ml} \mathrm{min}^{-1}\right)$ & 2 \\
\hline Make-up Flow $\left(\mathrm{ml} \mathrm{min}^{-1}\right)$ & 25 \\
\hline Retention time (min) & Bifenthrin \\
\hline
\end{tabular}


Table.2 Recovery bifenthrin residues in field bean

\begin{tabular}{|l|r|r|r|r|r|r|}
\hline \multirow{4}{*}{ Details } & \multicolumn{6}{|c|}{ Recoveries of bifenthrin from fortified field bean samples } \\
\cline { 2 - 7 } & \multicolumn{7}{|c|}{\begin{tabular}{c} 
Fortified level \\
\cline { 2 - 7 }
\end{tabular}} & \multicolumn{2}{|c|}{$\begin{array}{c}\text { 0.05 kg kg-1 } \\
\text { recovered } \\
\left(\mathrm{mg} \mathrm{kg}^{-1}\right)\end{array}$} & Recovery \% & $\begin{array}{c}\text { Residues } \\
\text { recovered } \\
(\mathrm{mg} \mathrm{kg}-1)\end{array}$ & Recovery \% & $\begin{array}{c}\text { Residues } \\
\text { recovered } \\
(\mathrm{mg} \mathrm{kg}-1)\end{array}$ & Recovery \% \\
\hline R1 & 0.0427 & 85.46 & 0.211 & 84.68 & 0.471 & 94.17 \\
\hline R2 & 0.0420 & 84.09 & 0.210 & 84.03 & 0.454 & 90.85 \\
\hline R3 & 0.0427 & 85.43 & 0.210 & 84.27 & 0.470 & 94.13 \\
\hline Mean & & 84.78 & & 84.36 & & 92.52 \\
\hline SD & & 0.963 & & 0.459 & & 2.35 \\
\hline RSD & & 1.14 & & 0.54 & & 2.54 \\
\hline
\end{tabular}

Table.3 Dissipation of bifenthrin 10\% EC (812 g a.i. ha-1) in field bean after three sprays

\begin{tabular}{|c|c|c|c|c|c|}
\hline \multirow[b]{2}{*}{ Daysafter last spray } & \multicolumn{4}{|c|}{ Residues of bifenthrin $\left(\mathrm{mg} \mathrm{kg}^{-1}\right)$} & \multirow[b]{2}{*}{ Dissipation \% } \\
\hline & R1 & R2 & R3 & Average & \\
\hline 0 & 2.64 & 2.59 & 2.65 & 2.62 & -- \\
\hline 1 & 1.75 & 1.76 & 1.72 & 1.74 & 33.59 \\
\hline 3 & 0.69 & 0.70 & 0.85 & 0.74 & 71.76 \\
\hline 5 & 0.25 & 0.23 & 0.19 & 0.22 & 91.60 \\
\hline 7 & BDL & BDL & BDL & BDL & 100 \\
\hline 10 & BDL & BDL & BDL & BDL & 100 \\
\hline 15 & BDL & BDL & BDL & BDL & 100 \\
\hline Regression equation & \multicolumn{5}{|c|}{$\mathrm{Y}=2.3841+(-0.4685) \mathrm{X}$} \\
\hline $\mathrm{R}^{2}$ & \multicolumn{5}{|c|}{0.9486} \\
\hline MRL & \multicolumn{5}{|c|}{ NA } \\
\hline Safe waiting period & \multicolumn{5}{|c|}{7 days } \\
\hline \multicolumn{6}{|c|}{$\begin{array}{l}\text { BDL- Below Determination Level } \\
\text { NA- Not Available }\end{array}$} \\
\hline
\end{tabular}

Fig.1 Dissipation of bifenthrin in field bean after three sprays

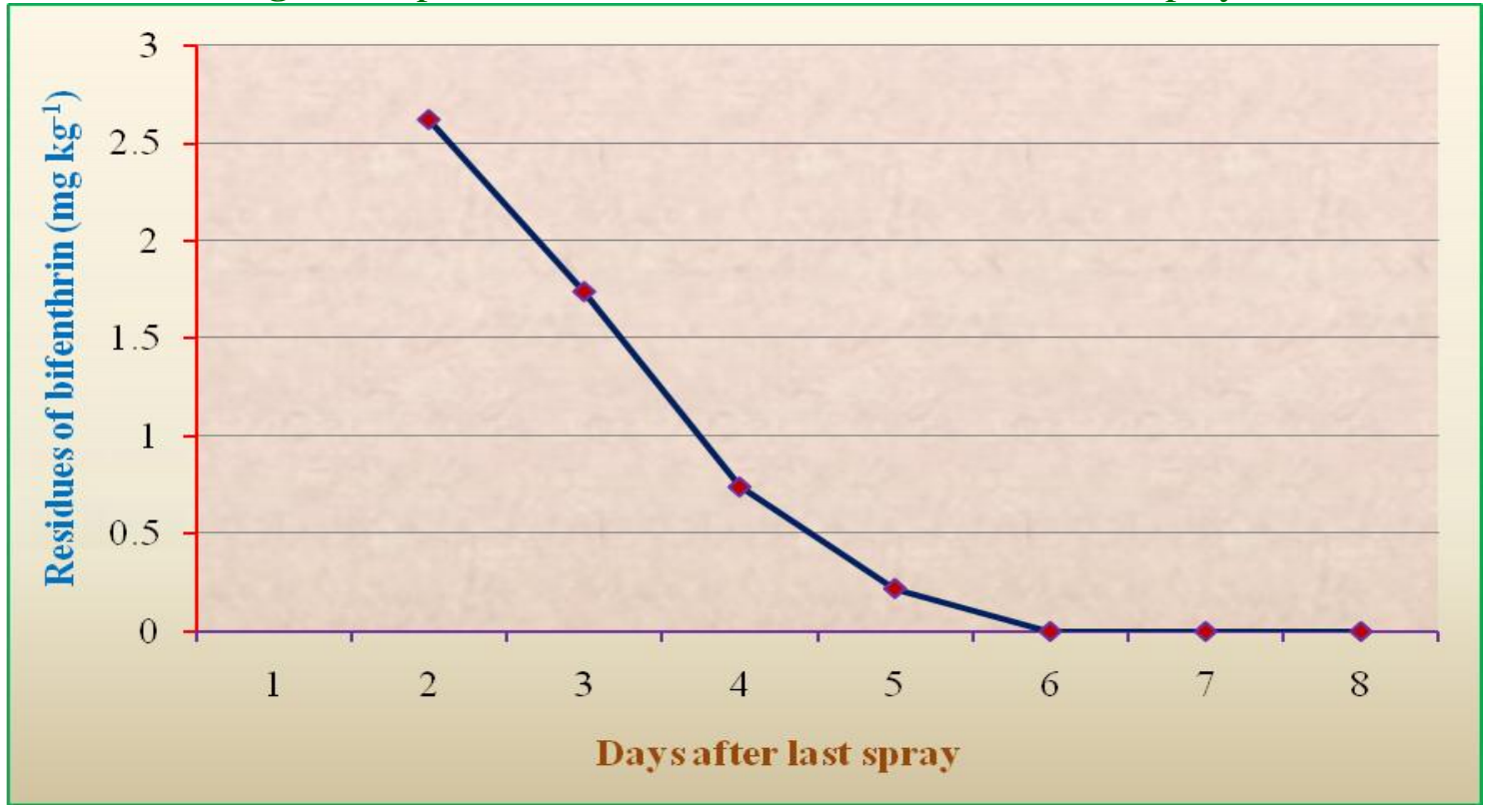




\section{Extraction and Clean $-\mathrm{Up}$}

Beans $(5 \mathrm{~kg})$ were homogenized with robot coupe blixer and homogenized

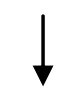

$15 \pm 0.1 \mathrm{~g}$ sample was taken in $50 \mathrm{ml}$ centrifuge tube

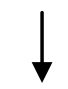

Required quantity of standard (CRM) added to get desired fortification level

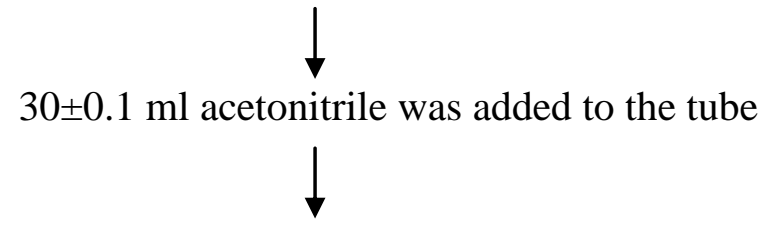

The sample was homogenized at 14000-15000 rpm for 2-3 min

Using Heidolph silent crusher

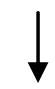

$3 \pm 0.1 \mathrm{~g}$ sodium chloride was added to tube and mixed by shaking gently

Centrifuged for $3 \mathrm{~min}$ at $2500-3000 \mathrm{rpm}$ to separate the organic layer

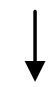

The top organic layer of about $16 \mathrm{ml}$ was taken into the

$50 \mathrm{ml}$ centrifuge tube

$9 \pm 0.1 \mathrm{~g}$ anhydrous sodium sulphate was added to remove the moisture content

$8 \mathrm{ml}$ of extract was taken in to $15 \mathrm{ml}$ tube containing

$0.4 \pm 0.01 \mathrm{~g}$ PSA sorbent (for dispersive solid phase d-SPE cleanup) and

$1.2 \pm 0.01 \mathrm{gr}$ anhydrous magnesium sulphate

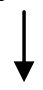

The sample tube was vertexed for $30 \mathrm{sec}$

Followed by centrifugation for $5 \mathrm{~min}$ at 2500-3000 rpm

The extract of about $2 \mathrm{ml}$ was transferred into test tubes and evaporated to

Dryness using turbovap with nitrogen gas and reconstituted with

1ml n-Hexane: Acetone (9:1) for GC analysis with ECD for profenophos analysis. 
The present investigation findings were differed from the findings of Patyal et al., (2010) who reported that persistence of bifenthrin at $60 \mathrm{~g}$ a.i.ha ${ }^{-1}$ and $120 \mathrm{~g}$ a.i.ha ${ }^{-1}$ on apple fruit and found the residues of bifenthrin initially in the range of $0.669-1.062 \mathrm{mg} \mathrm{kg}^{-1}$ at $60 \mathrm{~g}$ a.i.ha ${ }^{-1}$ dose and 1.348-1.784 mg kg-1 at $120 \mathrm{~g}^{-1 . i . h a^{-1}}$ dose which dissipated to half in 4.85-5.22 and 4.38-6.66 days, respectively and suggested safe waiting period of 2.1 to 5.4 and 6.7 to 11.3 days.

Katroju et al., (2014) reported that the dissipation pattern of bifenthrin $10 \mathrm{EC}$ when applied at the rate of $100 \mathrm{~g}$ a.i. ha ${ }^{-1}$ with two sprays of insecticide 10 days interval starting from fruit initiation stage. The initial deposit of bifenthrin was $0.85 \mathrm{mg} \mathrm{kg}^{-1}$ which dissipated to $0.39,0.15 \mathrm{mg} \mathrm{kg}^{-1}$ by $1^{\text {st }}$ and $3^{\text {rd }}$ day after last spray, respectively and to BDL by $5^{\text {th }}$ day.

Pre-harvest interval of 3 days was suggested for bifenthrin in tomato. The variation of initial deposits in the present investigation may be due to variation in climatic conditions, geographical location, matrix and dosage applied (Khay et al., 2008). Reddy et al., (2012) reported the dissipation pattern of bifenthrin $10 \mathrm{EC}$ when sprayed @ $50 \mathrm{~g}$ a.i. ha ${ }^{-1}$ at head formation stage of cabbage variety Varun followed first order degradation kinetics.

They observed that the initial deposit $(1.03 \mathrm{mg}$ $\mathrm{kg}^{-1}$ ) was dissipated below detectable level at 7 days after third spray. The waiting period suggested for safe harvest of cabbage heads after three sprays for bifenthrin was 5.16 days. Reddy et al., (2014) reported the residue dynamics of bifenthrin $10 \mathrm{EC}$ in cabbage when applied at the rate of $100 \mathrm{~g}$ a.i.ha ${ }^{-1}$. The initial deposits of $2.24 \mathrm{mg} \mathrm{kg}^{-1}$ bifenthrin recorded at 2 hours after last spray while, below determination level (BDL) by $10^{\text {th }}$ day. Based on the dissipation pattern a safe waiting period of 3 days was recommended for bifenthrin in cabbage.

The variation of initial deposits in the present investigation may be due to variation in dosage applied, climatic conditions and also matrix. Rama rao and Raja goud (2016) reported that the dissipation pattern of initial deposit of bifenthrin on tomato was $0.24 \mathrm{mg} \mathrm{kg}^{-1}$ which dissipated to below detectable level (BDL) by $10^{\text {th }}$ day after first spray in harvested tomato fruits.

The change in initial deposits in the present findings may be due to variation in climatic conditions and matrix (Khay et al., 2008).

\section{References}

Khay, S., Choi, J.H and Abd El-Aty, M.A. 2008.Dissipation behavior of lufenuron, benzoyl phenyl urea insecticides, in/on Chinese cabbage applied by foliar spraying under greenhouse conditions. Bulletin of Environmental Contamination and Toxicology. 81: 369-372.

Reddy, A. A., Vemuri, S and Cherukuri, S.R. 2014. Dissipation pattern of bifenthrin in cabbage (Brassica oleracea var. capitata). Indian Journal of Advances in Plant Research. 1 (3): 51-56.

Reddy, C.N., Reddy, D.J and Rahman, S.M.A. 2012. Persistence of fipronil and bifenthrin residues in cabbage. International Journal of Bio-Resource and Stress Management. 3 (1): 73- 74.

Schaaffhausen, R.V. 1963. Dolichos lablab or Hyacinth bean, its use for feed, food and soil improvements. Economic Botany. 17: 146-153.

\section{How to cite this article:}

Srinivasa Reddy, S., C. Narendra Reddy, C. Srinivas, A. Manohar Rao and Narendar Reddy, S. 2017. Dissipation Pattern of Bifenthrin on Dolichos Bean. Int.J.Curr.Microbiol.App.Sci. 6(8): 675680. doi: https://doi.org/10.20546/ijcmas.2017.608.085 